\section{Diálogos com a natureza na América Portuguesa}

\section{Por Christian Fausto Moraes dos Santos \\ Universidade Estadual de Maringá \\ (chfausto@hotmail.com)}

PAPAVERO, Nelson;

TEIXEIRA, Dante Martins;

FIGUEIREDO, José Lima de; BARROS-CORDEIRO,

Karine Brenda; PUJOL-

LUZ, José Roberto. A

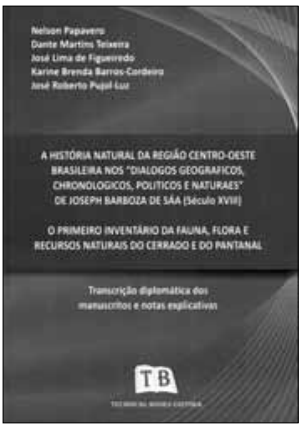

história natural da região

Centro-Oeste brasileira nos "Dialogos geograficos, chronologicos, politicos e naturaes" de Joseph Barboza

de Sáa (século XVIII): O primeiro inventário da fauna, flora e recursos naturais do Cerrado e do Pantanal. Rio de Janeiro: Technical Books, 2012. 299 p. ISBN 978-8561368-27-2

Foi em meados do século XVIII que um viajante, então radicado na Vila Reyal do Senhor Jesus do Cuyaba, concluiu uma das obras - que podemos, hoje, nos arriscar a afirmar - mais significativas da história da América Portuguesa. Os "Dialogos Geograficos, Politicos, e naturais, escriptos por Joseph Barboza de Sáa Nesta Vila Reyal do Senhor Bom Jesus do Cuyaba - Anno de 1769" foram escritos, como o título sugere, na forma de 21 diálogos entre um "curioso mancebo" e um "provecto varão". É uma das maiores, senão a maior, e mais complexa cosmologia já escrita na América Portuguesa.

Pouco se sabe sobre o advogado licenciado Joseph Barboza de Sáa. De suas obras conhecidas da comunidade acadêmica, como a transcrição da ata da fundação de Cuiabá, dada como perdida, restaram somente uma cópia transcrita a punho de Barboza de Sáa, bem como algumas considerações sobre um inventário feito após sua morte, no qual é listada a sua biblioteca, vendida pela viúva para dar sustento aos órfãos.
Com referência aos "Dialogos Geograficos...", objeto de análise dos pesquisadores Nelson Papavero, Dantes Martins Teixeira, José Lima de Figueiredo, Karine Brenda Barros-Cordeiro e José Roberto Pujol-Luz, ao que tudo indica, um dos principais objetivos de seu autor era compreender como surgiram as Américas, bem como as criaturas que as habitavam. A ideia de Barboza de Sáa era construir uma memória, tanto física quanto humana, para o Novo Mundo (em especial a América Portuguesa), à luz de obras, autores e teorias acolhidos pela Igreja Católica.

Certamente, foi o espírito investigativo de Barboza de Sáa que legou as centenas de descrições de animais, plantas e minerais do Cerrado e Pantanal mato-grossense, identificados e discutidos pelos autores. Mesmo sem ser um letrado nos padrões do século XVIII, Barboza de Sáa se ocupou, por exemplo, em explicar, a partir do paradigma bíblico da Arca de Noé, como a natureza americana tinha se tornado tão diversa. Segundo este advogado licenciado, o cerne da explicação para a diversidade das espécies poderia ser encontrado em fatores de ordem externa. Com o fim do dilúvio e o ancoramento da Arca no monte Ararat, os animais teriam se dispersado da mesma maneira que as plantas. O que Barboza de Sáa pretendia, com o exemplo das plantas, era demonstrar que os animais do Novo Mundo não foram simplesmente transportados até lá, e que a ocupação do continente americano, pelos mesmos, deu-se em consequência de um efeito de dispersão e colonização a partir de um centro de origem, ou seja, o monte Ararat.

Para explicar por que algumas espécies, encontradas no Velho Mundo, não existiam no continente americano, Barboza de Sáa vai buscar na influência climática e na adaptabilidade alguns de seus principais argumentos, pois que cada animal, ao sair da Arca, não foi desordenadamente se espalhando pelo globo. Para esse processo, Barboza de Sáa ponderava que existiam alguns fatores a serem considerados, entre eles, um relativamente simples e óbvio: cada espécie teria procurado como nicho o ambiente em que se sentia bem.

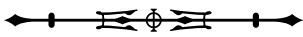


Como cristão, Barboza de Sáa via tais questões como primordiais à manutenção da fé em Deus. Afinal, desde fins do século $X V$, inquiria-se sobre o fato de que não havia nenhuma referência, nas Sagradas Escrituras, ao Novo Mundo e a seus habitantes. Assim como Joseph D'Acosta e Athanasius Kircher, Barboza de Sáa também se preocupou, em pleno século XVIII, em dar uma versão teológico-natural para o continente encontrado em 1492, algo bem demonstrado pelos autores do livro ao identificarem as espécies e os recursos naturais descritos nos "Dialogos Geograficos...".

Foi a partir destes componentes que os autores elaboraram uma primorosa edição comentada da obra de Barboza de Sáa, tendo como recorte o mundo natural. Cada um dos mais de 700 animais, plantas e produtos naturais descritos por Sáa foi devidamente catalogado, do 'mentrasto' (Peltodon radicans) ao 'cão gozo ordinário'
(Canis familiaris). Papavero e colaboradores listam, identificam, descrevem e comentam a ampla gama dos seres observados por Barboza de Sáa.

A criteriosa abordagem interdisciplinar possibilita que pesquisadores das mais diferentes áreas tenham, nos "Dialogos Geograficos...", não somente uma fonte documental, mas uma obra de referência para a história das ciências naturais no Brasil. Mais do que uma visão acerca da origem dos seres encontrados no Cerrado e Pantanal mato-grossense, os "Dialogos Geograficos..." são exemplo ímpar do esforço de um homem que, apesar dos parcos recursos financeiros e bibliográficos, tentou resolver uma das maiores questões que se apresentavam aos letrados, religiosos e curiosos desde 1492: a de como foram parar, no Novo Mundo, tantos animais, plantas e seres humanos. 